methylated 16-epioestriol it has been concluded that the Kober chromogen is identical with the latter. The amounts of 16-epioestriol found in the pooled extracts from both follicular phase (14th16th day) and luteal phase (22nd-24th day) urines were equivalent to about $1 \mu \mathrm{g}$. $/ 24 \mathrm{hr}$. urine volume. It is not unlikely that the true figure may be considerably higher than this.

\section{SUMMARY}

1. Evidence is presented which indicates that the 16-epioestriol isolated by Marrian \& Bauld (1955) from the urine of pregnant women was not an artifact formed by the epimerization of oestriol.

2. A method, based on that of Bauld (1953) for urinary oestriol, is described which permits of the rough determination of 16-epioestriol in pregnancy urine.

3. The amounts of 16-epioestriol determined in late-pregnancy urine after hot acid hydrolysis or after hydrolysis with $\beta$-glucuronidase (Patella vulgata) were within the range of $350-800 \mu \mathrm{g}$./ $24 \mathrm{hr}$. urine volume.

4. A '16-epioestriol-like' Kober chromogen has been detected in urine specimens collected from the 14th to 16th and from the 22nd to 24th days of the menstrual cycle in amounts equivalent to about $1 \mu \mathrm{g} . / 24 \mathrm{hr}$. urine volume.

5. Chromatographic evidence is presented which indicates that this Kober chromogen is identical with 16-epioestriol.

The authors acknowledge with thanks a grant from the Medical Research Council from which the cost of this work was defrayed, and the technical assistance of Miss W. Martin in certain phases of the work.

\section{REFERENCES}

Bauld, W. S. (1953). Ph.D. Thesis: University of Edinburgh.

Bauld, W. S. (1954). Biochem. J. 56, 426.

Bauld, W. S. (1955). Biochem. J. 59, 294.

Brown, J. B. (1952). J. Endocrin. 8, 196.

Brown, J. B. (1955). Lancet, 1, 320.

Dodgson, K. S. \& Spencer, B. (1953). Biochem. J. 55, 315.

Fishman, W. H. (1948). J. biol. Chem. 173, 449.

Huffman, M. N. \& Darby, H. H. (1944). J. Amer. chem. Soc. 66, 150.

Marrian, G. F. \& Bauld, W. S. (1954). Biochem. J. 58, xxxvi.

Marrian, G. F. \& Bauld, W. S. (1955). Biochem. J. 59, 136.

\title{
Biosynthesis of Proteins
}

\section{THE EFFECT OF INTRAVENOUS PEPTIDES ON CASEIN SYNTHESIS IN A LACTATING GOAT*}

\author{
By C. GODIN† AND T. S. WORK \\ National Institute for Medical Research, Mill Hill, London, N.W. 7
}

(Received 28 November 1955)

In earlier papers of this series (Campbell \& Work, 1952 ; Askonas, Campbell, Godin \& Work, 1955) we showed that plasma proteins provided little of the nitrogen required for casein synthesis in the lactating animal, and that any plasma protein which was converted into casein was first degraded completely to amino acids. From our results it was not clear whether the mammary gland was unable to use peptides or whether it might use peptides but was unable to produce them by partial degradation of plasma protein.

In the present investigation the mammary gland has been provided with a mixture of some of the peptides produced by partial acid hydrolysis of

* Part 3: Askonas, Campbell, Godin \& Work (1955).

$\dagger$ Postdoctorate fellow, National Research Council of Canada; present address: Faculty of Science, University of Ottawa, Canada. casein, and its ability to use these peptides for casein synthesis has been measured.

\section{EXPERIMENTAL}

Animal. A normal lactating goat with a daily milk yield of about $5 \mathrm{lb}$. was used.

Radioactive lysine. DL-[1-14C]Lysine was a sample prepared by Arnstein, Hunter, Muir \& Neuberger (1952).

Preparation of peptide mixture. Goat casein (10 g.) was suspended in $12 \mathrm{~N}-\mathrm{HCl}(100 \mathrm{ml}$.$) and heated in a sealed$ tube for $8 \mathrm{hr}$. at $56^{\circ}$. Excess of acid and acidic peptides were removed with ion-exchange resin (Deacidite E, The Permutit Co., London, W. 4) as described by Askonas et al. (1955), and the peptide mixture (974 mg. of N) in $200 \mathrm{ml}$. of acetic acid $(20 \%, v / v)$ was percolated through a column of washed charcoal (25 g.) (Schramm \& Primosigh, 1943), the percolate being washed through with a further $200 \mathrm{ml}$. of $20 \%$ acetic acid. The combined effluents from the charcoal contained $900 \mathrm{mg}$. of $\mathrm{N}$. 
Fractionation of peptide mixture. The method followed that described previously (Askonas et al. 1955). The resin (1.35 kg.) used was Zeo-Karb 225 WRl-1 (The Permutit Co.) which gave a column $5 \mathrm{~cm} . \times 70 \mathrm{~cm}$. The resin was equilibrated with ammonium formate buffer, $\mathrm{pH} 2 \cdot 46(0 \cdot 2 \mathrm{M})$, and the peptide mixture (previously freed from as much acetic acid as possible by vacuum distillation) was added to the column in the same buffer. The column was developed with pH 2.46 buffer at a flow rate of $80 \mathrm{ml}$./ hr. until $3.5 \mathrm{l}$. of effluent had been collected and then with pH 5.5 buffer (2M) until the total volume of effluent was 171 .

Detection of lysine peptides. Since we proposed to use the distribution of radioactive lysine as a measure of the utilization of lysine peptides, the column effluent (collected in $50 \mathrm{ml}$. lots) had to be analysed for lysine peptides. The 335 individual fractions were evaporated to dryness in a multiple-sample evaporator (Askonas et al. 1955) and a small sample from every third fraction was hydrolysed at $105^{\circ}$ with $6 \mathrm{~N}-\mathrm{HCl}$ for $20 \mathrm{hr}$. The hydrolysate was analysed by single-dimension paper chromatography, with butanolacetic acid as solvent. Each hydrolysed fraction was run side by side with an unhydrolysed sample from the same $50 \mathrm{ml}$. of effluent. In a representative column, fractions 1-78 $(A)$ contained no lysine peptides, fractions 79-109 $(B)$ contained lysine peptides, 110-120 $(C)$ contained free lysine and lysine peptides, 121-170 (D) contained lysine peptides, and 171-335 $(E)$ contained little lysine peptide.

Quantitative estimation of lysine in lysine peptides. Free lysine and total lysine in the lysine peptides were determined with lysine decarboxylase. Samples $(0.5 \mathrm{mg}$. of $\mathrm{N})$ of each peptide mixture were hydrolysed with $6 \mathrm{~N}-\mathrm{HCl}$ at $105^{\circ}$ for $20 \mathrm{hr}$. Acid was removed in the usual way in vacuo, and the sample, dissolved in $0.2 \mathrm{M}$ phthalate buffer, pH 5.3 (0.5 ml.), was added to $3 \mathrm{mg}$. of enzyme in phthalate buffer $\left(2.5 \mathrm{ml}\right.$.) in a Warburg apparatus at $30^{\circ}$. The enzyme preparation was an acetone-dried powder of Bacillus cadaveris NCTC 6578 grown on Hedley Wright broth.

Isolation of bisdinitrophenyllysine. To isolate bisdinitrophenyllysine from each group of lysine peptides, each was hydrolysed at $105^{\circ}$ in $6 \mathrm{~N}-\mathrm{HCl}$ for $20 \mathrm{hr}$. The bulk of the HCl was removed in vacuo, and the residue diluted with water until the acid concn. was about $2 \mathrm{~N}$. Phosphotungstic acid $(25 \%, \mathrm{w} / \mathrm{v})$ in $2 \mathrm{~N}-\mathrm{H}_{2} \mathrm{SO}_{4}$ was added until no further precipitate formed. The precipitate, after washing with phosphotungstic acid in $\mathrm{H}_{2} \mathrm{SO}_{4}$, was decomposed with excess of $\mathrm{Ba}(\mathrm{OH})_{2}$ and excess of $\mathrm{Ba}^{2+}$ removed as $\mathrm{BaCO}_{3}$. The solution of basic amino acids was treated with fluorodinitrobenzene and $\mathrm{NaHCO}_{3}$ in the usual way, and the resultant mixture of dinitrophenylamino acids was fractionated on silica as described by Askonas et al. (1955). The bisdinitrophenyllysine was crystallized from formic acid, weighed and diluted with a suitable quantity of synthetic bisdinitrophenyllysine before counting at infinite thickness. All counts were to a s.E. of $\pm 2.5 \%$.

\section{RESULTS}

\section{Casein peptides for intravenous injection}

A partial acid hydrolysate of goat casein was fractionated on an ion-exchange column as indicated in the Experimental section and divided into five groups of peptides as indicated in Table 1. One group of lysine peptides $(B)$ was clearly separated
Table 1. Distribution of lysine peptides after fractionation of a partial hydrolysate of casein on ZeoKarb 225 WR1.1 resin

For details see text.

\begin{tabular}{lccc}
\multicolumn{1}{c}{ Fraction } & $\begin{array}{c}\text { Total N } \\
\text { (mg.) }\end{array}$ & $\begin{array}{c}\text { Free lysine } \\
\text { (mg.) }\end{array}$ & $\begin{array}{c}\text { Total lysine } \\
\text { (mg.) }\end{array}$ \\
$A(1-78)$ & 490 & None & None \\
$B(79-109)$ & 201 & None & $26 \cdot 5$ \\
$C(110-120)$ & 60 & ++ & ++ \\
$D(121-170)$ & 81 & $2 \cdot 8$ & $64 \cdot 5$ \\
$E(171-335)$ & 44 & - & +
\end{tabular}

Where no definite figure is given for free lysine or total lysine the determinations were only semiquantitative (paper chromatography). Where definite figures are given determinations were with lysine decarboxylase before and after acid hydrolysis.

from another group $(D)$ by a band containing mainly free lysine. It is clear from the table that fraction $D$ was particularly rich in lysine peptides, bound lysine accounting for $14.5 \%$ of the total nitrogen of this fraction.

Fraction $D$ was dissolved in $10 \mathrm{ml}$. of water, together with $32.7 \mathrm{mg}$. of radioactive lysine $\left(20 \mu \mathrm{C}\right.$ of $\left.{ }^{14} \mathrm{C}\right)$ and the $\mathrm{pH}$ adjusted to $7 \cdot 4$. This mixture was injected intravenously into the goat immediately after milking the animal dry. Two hours later the animal was milked dry again and the casein (13 g.) separated from the milk in the usual way (Askonas, Campbell \& Work, 1954).

\section{Distribution of radioactivity in casein synthesized after intravenous administration of peptides}

To determine whether the injected peptide mixture had been used directly for casein synthesis, it was necessary only to carry out a partial hydrolysis of the $2 \mathrm{hr}$. casein sample and to see whether the presence of lysine peptides in the blood had resulted in non-uniform labelling of the casein (cf. Askonas et al. 1955). Hydrolysis and fractionation of this casein was carried out in exactly the same way as in the preparation of the peptide mixture for injection (see Experimental). The effluent from the ion-exchange column was analysed qualitatively by single-dimension paper chromatography and the peptides were grouped as shown in Table 2.

Each group of lysine peptides was hydrolysed and the lysine isolated and crystallized as bisdinitrophenyllysine by the methods of Askonas et al. (1955). The results of radioactivity determinations are given in Table 2.

\section{DISCUSSION}

Any attempt to show that peptides can be used for protein synthesis faces the problem of choosing a suitable test peptide sequence out of the infinite 
Table 2. Distribution of radioactivity in lysine peptides obtained by fractionation of a partial hydrolysate of the casein formed during $2 \mathrm{hr}$. after injection of a mixture of $\left[{ }^{12} \mathrm{C}\right]$ lysine peptides and $\left[{ }^{14} \mathrm{C}\right]$ lysine into a lactating goat

The casein (10 g.) was hydrolysed and fractionated as described for non-radioactive casein (see Experimental), the effluent from the Zeo-Karb 225 column (1.35 kg.) being collected in $50 \mathrm{ml}$. fractions. Radioactivity expressed as counts $/ \mathrm{min}$. Under the conditions used $1 \times 10^{-3} \mu \mathrm{c} / \mathrm{mg}$. of $\mathrm{C}$ gives 1000 counts/min. The amount of lysine peptide $(+$ to ++++$)$ was estimated semiquantitatively by paper chromatography before and after acid hydrolysis.

$\begin{array}{cccc}\begin{array}{c}\text { Fraction } \\ \text { no. }\end{array} & \begin{array}{c}\text { Lysine } \\ \text { peptides }\end{array} & \begin{array}{c}\text { Free } \\ \text { lysine }\end{array} & \begin{array}{c}\text { Mean specific } \\ \text { radioactivity } \\ \text { of lysine }\end{array} \\ \begin{array}{c}\text { 1-69 } \\ 70-82\end{array} & \text { None } & \text { None } & - \\ 83-97 & \text { Trace } & \text { None } & - \\ 98-110 & +++ & \text { None } & 985 \\ 111-123 & ++++ & \text { None } & 1020 \\ 124-133 & ++++ & +++ & - \\ 134-150 & ++ & \text { None } & 1070 \\ 151-170 & ++ & \text { None } & 1030 \\ & & & \end{array}$

variety of sequences which could be presented to the cell. Although from previous work (Askonas et al. 1955) we had some slight knowledge of the peptide sequences in casein, there seemed no reason why we should choose one peptide sequence rather than another to test its availability for casein synthesis. It seemed preferable therefore to use a complex mixture of peptides obtained by partial hydrolysis of casein and to devise a test whereby we should be able to detect the direct use of any peptides in this mixture.

By separating a partial hydrolysate of casein into two large groups of lysine peptides and injecting only one group we were able to provide an internal control in a single animal. It would have been preferable to have used radioactive peptides, but this would have required the use of a considerably larger quantity of ${ }^{14} \mathrm{C}$. During the period immediately following the injection of the mixture of lysine peptides and ${ }^{\left[{ }^{14} \mathrm{C}\right] l y s i n e}$ the mammary gland had the opportunity of using either $\left[{ }^{12} \mathrm{C}\right]-$ lysine present as lysine peptides or $\left[{ }^{14} \mathrm{C}\right]$ lysine as free lysine. Any $\left[{ }^{12} \mathrm{C}\right]$ lysine peptide used directly for casein synthesis would lower the mean specific radioactivity of lysine in the resultant casein. The results given in Table 2 show that in the $2 \mathrm{hr}$. casein the lysine peptides with high $R$ value on Zeo-Karb were no more active than the peptides with low $R$ values, although unlabelled peptides of only the latter type had been injected. It is unlikely therefore that any significant use was made of the injected peptides for casein synthesis.

In the present investigation, as in all similar investigations, the complications due to permeability barriers are unpredictable. Since, however, no example is yet known of net protein synthesis in disintegrated mammalian cells, such complications are unavoidable. What little evidence there is (cf. Christensen \& Rafn, 1952) suggests that at least some peptides can pass freely across mammalian cell walls, and it seems likely that the failure of the mammary gland to make direct use of plasma peptides for protein synthesis is the reflexion of a general inability of cells to incorporate peptides into proteins without first degrading them to amino acids. If, as suggested by Hoagland (1955), the first step in protein synthesis is the carboxyl activation of amino acids, then this limitation would be reasonable.

\section{SUMMARY}

1. A partial acid hydrolysate of goat casein was fractionated into two groups of lysine peptides, and one of these was injected into a lactating goat together with radioactive lysine.

2. The casein synthesized during the $2 \mathrm{hr}$. following injection was partially hydrolysed, and the distribution of radioactivity in the resultant peptide mixture was determined.

3. The injection of lysine peptides did not alter the uniform distribution of $\left[{ }^{14} \mathrm{C}\right]$ lysine between different peptides.

4. The results indicate that peptides circulating in the blood cannot be used for casein synthesis without prior degradation to amino acids.

We wish to thank Dr J. Mandelstam for providing lysine decarboxylase.

\section{REFERENCES}

Arnstein, H. R. V., Hunter, G. D., Muir, H. \& Neuberger, A. (1952). J. chem. Soc. p. 1329.

Askonas, B. A., Campbell, P. N., Godin, C. \& Work, T. S. (1955). Biochem. J. 61, 105.

Askonas, B. A., Campbell, P. N. \& Work, T. S. (1954). Biochem. J. 58, 326.

Campbell, P. N. \& Work, T. S. (1952). Biochem. J. 52, 217. Christensen, H. N. \& Rafn, M. L. (1952). Cancer Res. 12, 495.

Hoagland, M. B. (1955). Biochem. biophys. Acta, 16, 288. Schramm, G. \& Primosigh, J. (1943). Ber. dtsch. chem. Ges. $76 \mathrm{~B}, 373$. 